\title{
バイオマス活用における担い手別の経済性と地産地消効果
}

\section{Profitability of Each Person in Charge and Effect of Local Production for Local Consumption by Biomass Utilization}

\author{
清水夏樹* 柚山義人** 中村真人** 山岡 賢** \\ Natsuki SHIMIZU* Yoshito YUYAMA** Masato NAKAMURA**and Masaru YAMAOKA** \\ (*京都大学学際融合教育研究推進センター森里海連環学教育ユニット **農研機構農村工学研究所)
}

(*Educational Unit for Studies on the Connectivity of Hilltop, Human and Ocean, C-PIER **Institute for Rural Engineering, NARO)

\section{I はじめに}

バイオマス活用推進基本計画(2010 年 12 月閣議決定。 以下，基本計画)では，市町村バイオマス活用推進計画の 策定および計画でのバイオマス活用の取組の効果の客観 的検証，エネルギーやバイオマス由来製品の自給率(地産 地消率)の算出が求められている。すなわち,これまで以 上に，計画対象「地域」でのバイオマス活用における効果 を明確に把握することが必要とされてきている。既往の 研究では，バイオマス由来エネルギーの地産地消によっ て，エネルギーの地域安全保障や新産業創出による地域 活性化，さらにバイオマスを生産する土地資源の適正管 理・二酸化炭素排出削減等による環境保全効果などが期 待できることが，木質バイオマスを中心に報告されてき

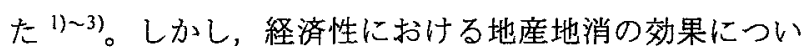
ては，広域的あるいは複合的なバイオマス活用を示唆す るに留まっている 1)，3)。また，廃萧物系バイオマスのメ タン発酵については，変換工程の事業採算性に関する研 究はあるものの ${ }^{4) ~}$ ，生成物の利用が「地域」にもたらす 経済的な効果については取り上げられていない。本稿で は，清水ら ${ }^{7)}$ 肪算出したバイオマス活用の段階別の収 入・ヨストの值を用い, バイオマス活用の各段階で支払 われるコストがどの程度地域内の収入獲得機会に結びっ くか，を検討することにより，エネルギーやバイオマス 由来製品の地産地消による経済面での効果について考察 を行った。

清水ら 7)では，都市近郊農業地域である千葉県香取市 を事例として，複数のバイオマスを対象に地域のバイオ マス活用におけるライフサイクルを「生産（発生）」から 「変換」，「生成物の利用」までの5つの段階(以下，ステー ジ)で表している。そして各ステージを，「実態」(活用前) と「計画」が対になるようにシナリオとして表現し，詳細 に設定した条件に基づいて，ステージ別のコストと収入
を算出した。「計画」では，バイオマスの変換によって生 成されるエネルギ一やマテリアルが，そのライフサイク ルの中でできるだけ「地域」内で利用される(地産地消さ れる)設計となっている。本稿では，複数の対象バイオマ スのうち，豚ふん尿を対象としたシナリオの算出結果を 用い，バイオマス活用に係る各ステージの担い手に着目 してコストと収入を整理し，担い手別の経済性を評価し た。そのため，特に記述のない限り，シナリオの対象， 各条件の設定および施設規模, 機器, 物質量, 価格等の 数值はすべて清水ら より引用した。担い手に着目した のは，ライフサイクルを通じたバイオマス活用の円滑な 推進のためには，各ステージの担い手が持続的に存在す ることが不可欠であり，各担い手の収入およびコスト負 担の状況が担い手の継続的な存在に影響を与えると考え たためである。また，地産地消の範囲を行政単位(市)之 した。これは，本稿での議論を，基本計画で策定を求め られている市町村バイオマス活用推進計画の効果的な実 現のための基礎情報とするためである。

IIシナリオの設定とコスト・収入の算出方法

\section{1 シナリオの対象}

シナリオの対象地域は，既往研究 7で評価対象とされ た千葉県香取市である。香取市の経営耕地面積(2010 年 農業センサス)は，田 6,782ha，畑 2,008haである。また畜 産業も盛んな地域であり，とりわけ養豚業は市の畜産産 出額の約 6 割を占める ${ }^{8)}$ 。香取市におけるバイオマス賦 存量調查 ${ }^{8)}$ の結果, 市内の家畜ふん尿発生量 $(353,251 \mathrm{t} /$ 年) の約 70\%を占める豚ふ九尿は，洗浄排水も含まれている ため含水率が高く，ほとんどが污水処理され河川に放流 されている ${ }^{8)}$

対象としたバイオマスは，既往研究 7のとおり，子取 り用雌豚 $170 \sim 180$ 頭規模の一貫経営養豚農家汒 ${ }^{11,2)} 10$ 戸 
から発生する $47,674 \mathrm{t} /$ 年の豚ふん尿と，同時に発生する 洗浄排水 49,064t/年を合わせた $96,738 \mathrm{t} /$ 年の豚ふん尿排水 である。対象養豚経営の規模と戸数は，地域の飼養規模 別養豚戸数および現地ヒアリング調查に基づき，「計画」 で仮定する変換工程の導入がある程度可能と考えられる 規模・戸数とした。飼養頭数は千葉県の平均とほぼ同じで あり，当該地域の平均的規模の養豚農家がバイオマス活 用に取り組んだ場合の効果を把握できると考えた。また， 生成されるメタン発酵消化液(以下，消化液)の全量を市 内の農地で施用(消費)することをシナリオの設計条件と した。そのため，市内の一部の養豚農家のみがコスト・ 収入の算出対象となっている。

\section{2 バイオマス活用のステージ}

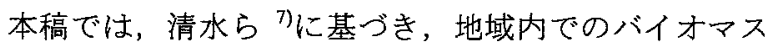
活用について，(1)バイオマスの生産(発生), (2)(原料バイ オマスの)収集・輸送・貯蔵, (3)バイオマスの変換, (4)生 成物の輸送・貯蔵, (5)生成物の利用, の5つのステージ(以 下，個別ステージについては S(1)〜(5)と表記)の連続と捉 えた。各ステージは，施設や機器装置等の「建設・製造段 階」, 施設の運転やサービス提供の「運営段階」，施設や機 器の「廃棄段階」の3つのライフサイクルが含まれる。

3. 実態シナリオと計画シナリオ ${ }^{7}$
豚ふん尿は養豚農家経営内で固液分離され，液体分は 污水処理後, 河川放流される。この現在の状況を実態シ ナリオ(以下，「実態」)と呼ぶ。「実態」と同条件で発生す る豚子ん尿について，養豚農家経営内で脱水後にメタン 発醉し，生成したバイオガスをエネルギーに変換，また 消化液を地域内農地に施用する計画を作成した。これを 計画シナリオ(以下，「計画」)と呼ぶ。図 1 は, 清水ら》 に基づき作成した，「実態」と「計画」の評価対象範囲のフ ローと各ステージの担い手, およびュストの発生場所(地 域内・地域外)別の算出詨象項目(システムフロー内に含 まれるものを除く)を示したものである。

「実態」では，ふんの $50 \%$ が豚舎で取り除かれ(除ふん 率 $50 \%$ は畜舎設計に用いられる最小値 ${ }^{9)}$ ，ただし除ふん に係るコストは算出対象外), 洗浄排水と合わせて養豚農 家 1 戸当たり $25 \mathrm{t}$ /日が，各養豚農家において固液分離 された後, 固体分は堆肥化, 液体分は污水処理装置で処 理して河川放流される。固体分の堆肥化工程については 算出対象外とした。この工程では，養豚頭数とそれに基 づく污水処理施設の設計值, 目標処理水質を基に污水量 や運転条件を仮定した 7。 。ま，地域内の農地では，地 域外から購入した化学肥料を基肥に使用して，農作物を 栽培する。化学肥料使用量は，千葉県施肥基淮の基肥窒

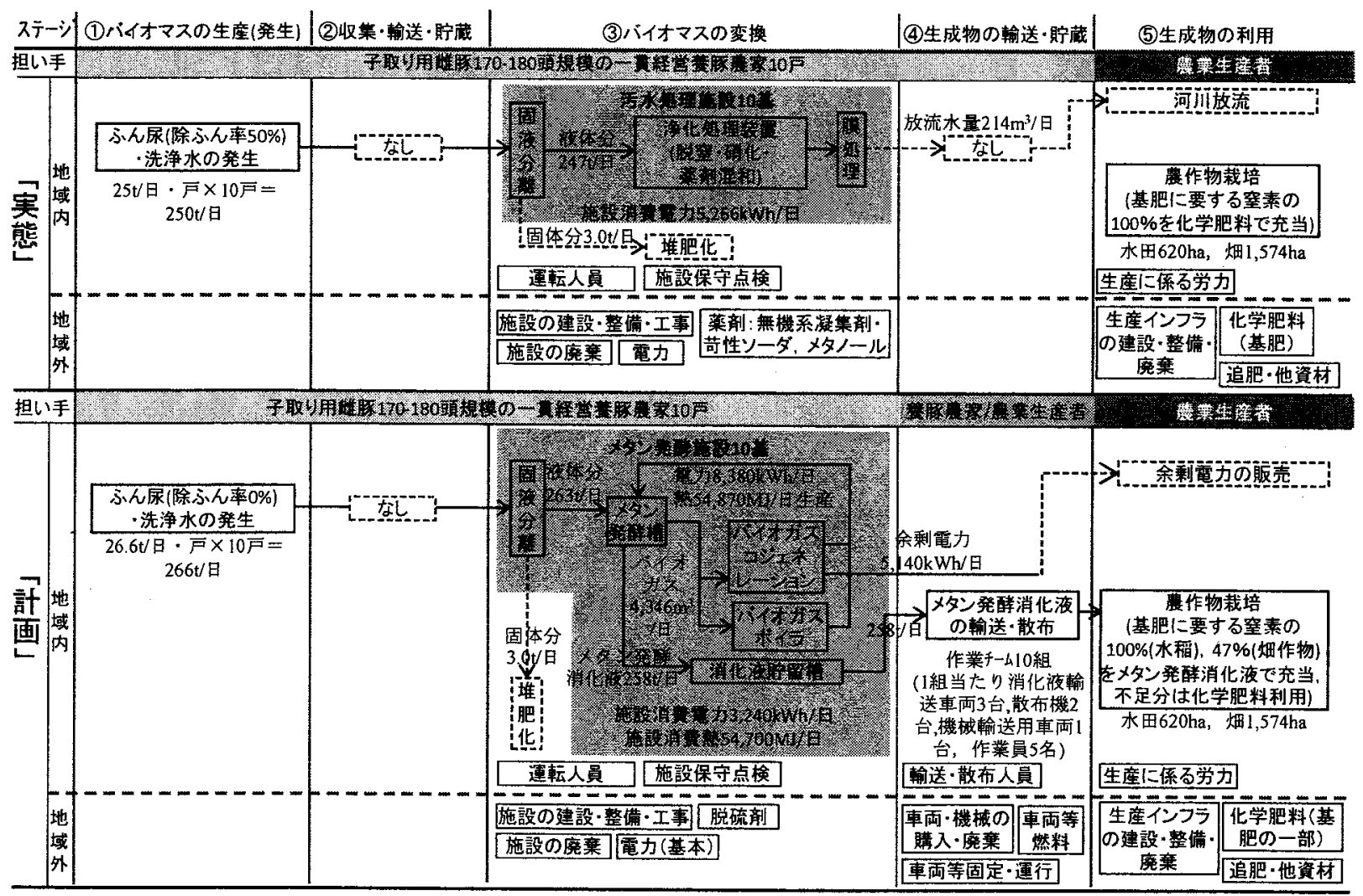

凡例: $\square \rightarrow$ 本稿で算出対象としたブロセスおよび項目、フロー

:-

注) 図中の数值は，引用文献 7)による(以下，表 1〜3も同様)

図 1 「実態」と「計画」の評価範囲と各ステージの担い手, 地域内・地域外別算出対象

Fig.1 System boundary of Present and Plan Scenario with person in charge of each stage 
素要求量（水田 $3.5 \mathrm{kgN} / 10 \mathrm{a}$ ，烟（主な作目の平均 值) $15 \mathrm{kgN} / 10 \mathrm{a}$ )に基づき普通化成肥料(窒素成分含有率 8\%)に換算して求めた。「実態」の S(1)〜(4)の担い手は養 豚農家，S(5)担い手は農業生産者である。

「計画」では，除ふん率を $0 \%$ と想定し，洗浄排水と合 わせて発生する豚ふん尿は養豚農家 1 戸当たり 26.6t/日 とした。豚ふん尿排水は，各養豚農家に設置されたメ夕 ン発酵施設で固液分離後メタン発酵される。生成したバ イオガスを用いたコジェネレーション装置により電力と 熱が生成されると同時に消化液が生成される。固液分離 により発生する固体分は堆肥化されるが，算出対象外と した。消化液は，車両で地域内の水田 620ha，畑 1,574ha に輸送し，専用の散布機を用いて散布し，農作物栽培の 基肥として利用する。消化液の害素成分 $\left(\mathrm{NH}_{4}-\mathrm{N}\right.$ 換算で $1,400 \mathrm{mg} / \mathrm{L}^{7)}$ )に基づき，化学肥料(普通化成肥料)が代替で きるとした。水田では消化液で化学肥料の $100 \%$ 代替 可能であるが，畑では消化液が高含水率であるため，散 布量は $5 \mathrm{t} / 10 \mathrm{a}$ を上限とした。よって窒素要求量の $47 \%$ 絮 消化液で代替され，53\%分は化学肥料によって補うこと とした。「実態」と同様に，S(1)〜(4)の担い手は養豚農家， S(5)の担い手は農業生産者であるが，S(4)についてはN章 で農業生産者が担う場合についても試算した。

これらの条件に基づき，各シナリオの各ステージにつ いてコストと収入を算出し「「実態」と「計画」を比較する ことによって, 経済効果を把握した。ただし、「実態」と「計 画」の条件が同じ場合には，差がない(効果も同じ)とみな し，コスト・収入の算出結果は明示していない。

\section{4 収入とコストの算出值の整理}

前述したように，本稿で用いた収入・コストの算出方
法および算出值は，すべて清水ら 7による。本稿では， 各ステージが，どこ(地域内または地域外)で，誰(担い手) によって行われるか，に着目して算出值を再整理した。 $\mathrm{S}$ (3)のめに設置される処理・変換の施設は，「実態」「計 画」とも養豚経営敷地内に建設されると考え, 新たな土地 取得のコストは 0 円と設定した。

施設や機器装置等の建設・製造に必要な資材は地域外 から調達され，また工事および廃棄段階についても地域 外の事業者が行うと考えた。そのため，施設等の「建設・ 製造段階」と「廃裹段階」のコストは，地域内から地域外 と支払われる。また，「運営段階」のコストのうち，光熱 費，地域内で調達できない原料・資材費は地域外へと支 払われる。一方, 人件費や保守点検費, 事務経費や手数 料は，地域内に支払われるコストである。詳細なコスト と収入の算出結果は，次章で述べる。

III 各ステージ別のコストと収入の算出結果

\section{1 ステージ別のコストと収入}

（1）バイオマスの生産 (発生) ステージ (S(1))

「実態」と「計画」では，除ふん率の違いに伴い，豚ふん 尿排水の発生量は異なるが，除ふんに係るコストを算出 対象外としたため，S(1)に係るコストには差はない。ま た，対象バイオマス由来の生成物やサービスはないため, 収入は0円である。

(2) 収集・輸送・貯蔵ステージ（S(2)）

「実態」「計画」とも，各養豚農家内で次のS(3)に供さ れるため，S(2)ではコスト・収入は計上しない。

(3) バイオマスの変換ステージ (S(3)

表 1 バイオマスの変換ステージ（S(3)の「実態」と「計画」における コストと収入(養豚農家 1 戸当たり)

Table 1 Cost and income in biomass conversion stage of Present and Plan for each pig breeder

\begin{tabular}{|c|c|c|c|c|c|c|c|}
\hline & \multirow{2}{*}{ 段階 } & \multicolumn{3}{|c|}{ 「実態」におけるコストと収入 } & \multicolumn{3}{|c|}{ 「計画」におけるコストと収入 } \\
\hline & & 項目名 & 金額 & 柿 & 項目名 & 金額 & 竐 \\
\hline \multirow{9}{*}{$\begin{array}{l}\vec{z} \\
\pi \\
\kappa\end{array}$} & \multirow{2}{*}{$\begin{array}{c}\text { 建設 } \\
\text { · } \\
\text { 製造 }\end{array}$} & $\begin{array}{l}\text { 污水処理施設(構造物)建設·工 } \\
\text { 事コスト卜(使用年数 } 30 \text { 年) }\end{array}$ & 860 千円/年 & \multirow{9}{*}{18,737 千 M/ $/$ = } & $\begin{array}{l}\text { メタン発醉施設(構造物)建 } \\
\text { 設コスト(使用年数 } 30 \text { 年) }\end{array}$ & 2,280 千円/年 & \multirow{9}{*}{$27596+1 / 4 / 4$} \\
\hline & & 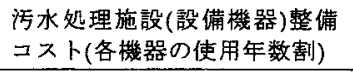 & 1,293 千円 $/$ 年 & & $\begin{array}{l}\text { メタン発醉施設(設備機器) } \\
\text { 整備コスト(使用年数 } 12 \text { 年) }\end{array}$ & 14,000 千月/年 & \\
\hline & \multirow{2}{*}{ 廃裹 } & $\begin{array}{l}\text { 污水処理施設(構造物)廃裹コ } \\
\text { スト }\end{array}$ & 29 千円/年 & & $\begin{array}{l}\text { メタン発醉施設(構造物)廃 } \\
\text { 賫コスト }\end{array}$ & 114 千丹/年 & \\
\hline & & $\begin{array}{l}\text { 污水処理施設(設備機器)廃㶳 } \\
\text { コスト }\end{array}$ & 39 千円/年 & & $\begin{array}{l}\text { メタン発酵施設(設備機器) } \\
\text { 廃㲤コスト }\end{array}$ & 420 千丹/年 & \\
\hline & \multirow{5}{*}{ 運営 } & 人件費 $(0.7 \text { 人 })^{*}$ & 3,150 千出/年 & & 人件费 $\left(1.5\right.$ 人)* ${ }^{3}$ & 6,750 千円/年 & \\
\hline & & 電力料金(基本 ·従畺電力料金) & 2,782 千円 $/$ 年 & & 電力料金(基本料金) & 304 千月/年 & \\
\hline & & \multirow{2}{*}{$\begin{array}{l}\text { 薬剂费(無機系凝集剤等・苛性 } \\
\text { ソーダ・メタターール) }\end{array}$} & \multirow[t]{2}{*}{ 10,061 千円/年 } & & 電力料金(従量料金) & $\begin{array}{l}\text { 施設内で生成で } \\
\text { きるため0円/年 }\end{array}$ & \\
\hline & & & & & 薬剤贵(脱硫剂) & 368 千円/年 & \\
\hline & & 保守点検費* & 523 千月/年 & & 保守点検費* & 3,360 千円/年 & \\
\hline \multirow{3}{*}{\multicolumn{2}{|c|}{ 収入 }} & \multirow{3}{*}{ なし } & \multirow{3}{*}{ 0円/年 } & \multirow{3}{*}{0 丹/年 } & 消化液販志* & 5,650 千円/年 & \multirow{3}{*}{$9,402 千 \mathrm{f} / /$ 年 } \\
\hline & & & & & 余剩電力販売* & 3,752 千円/年 & \\
\hline & & & & & Sん尿処理料(委託費収入)* & $\begin{array}{l}0 \text { 月/年(養豚経営 } \\
\text { 内であるため) }\end{array}$ & \\
\hline
\end{tabular}

注)項目名に゙があるものは地域内，それ以外は地域外 
S(3)の担い手は，養豚農家である。「実態」と「計画」に おける養豚農家 1 戸当たりのコストと収入を算出した結 果を表 1 に示す。「実態」では，S(3)でのコストは総額 $18,737 千$ 千年/戸となり，肥育豚 1 頭当たりに換算(子取 り用雌豚の平均頭数 175 頭規模は肥育豚 1,750 頭に該当， 1戸当たりコストを肥育豚頭数で除した)すると，ふ九氺 処理コスト(ただし廃棄段階を除く)は 10,668 円顗となつ た。「計画」のS(3)でのコストは，総額 27,596 千円/年/戸 となり，廃葉段階を除いて肥育豚1頭当たりに換算(「実 態」に同じ)すると，15,464 円頭となった。また，S(3)で は，1施設当たり 25.8t/日生成される消化液を製品として 販売するとともに，コジェネレーションで生産した熱の 全量と電力の $39 \%$ を施設内で使用し，余剩電力を電気事 業者(地域内への供給とみなす)に販売する社3)。

（4）生成物の輸送・貯蔵ステージ(S(4))

「実態」では，污水処理後の水は河川放流されるため， コストも収入も発生しない。「計画」では，消化液の輸送 および散布について,メタン発酵施設 1 基(養豚農家 1 戸) 当たりのコストと収入を算出した（表 2)。対象地域の作 業道の幅員等に配慮して輸送用車両の大 きさを設定したため，施設 1 基につき 5 名の作業員が必要となり，それゆえに運 営段階における人件費がステージ全体の コストの約 $60 \%$ を占めることとなった。 地域内の農業生産者が，消化液の輸送・ 散布サービスに対して手数料を支払い， S(4)の収入となる。

（5）生成物の利用ステージ(S(5))

表 3 に，S(5の「実態」と「計画」におけ るコストと収入を算出した結果を示す。 「実態」と計画」の条件が同じ項目ではコ
ストは算出していない。また，収穫物の収量(水稲反収は $550 \mathrm{~kg} / 10 \mathrm{a}$ とした)も同じとし，「計画」では「実態」からの 増収分のみを算出した。

「実態」では，バイオマス由来の生成物はないため，水 田 620ha，畑 1,574haで施用される基肥は全量，「地域外 から購入する化学肥料とした。10a 当たりの基肥コスト (化学肥料購入費)は，水田で 4,725 円，畑で 20,250 円で ある。「計画」では，S(4)で輸送・散布された消化液によ り，水田の基肥に要する化学肥料を $100 \%$ 削减できるた め,生産した米は「特別栽培米」(化学肥料を $50 \%$ 以上削減 して栽培)として通常の米よりも $1 \mathrm{~kg}$ 当たり 20 円高い価 格で販売できると仮定した。畑では，化学肥料削減率が 50\%末満であるため，収量・質ともに「実態」と同じであ り，生産物の販売価格の差はないとみなした。表 3 に示 す消化液に費やされるコストは，S(3)の担い手に支払う 購入費と，S(4)の担い手に支払う手数料の合計である。 $10 \mathrm{a}$ 当たりの基肥コスト(消化液購入と散布手数料，畑の 場合は補完する化学肥料購入費を含む)は，水田で 4,500 円，畑で 16,800 円となった。また，化学肥料を $100 \%$ 削

表 3 生成物の利用ステージ(S(5)の「害態」と「計画」におけるコストと収入(対象バイオマス全体)

Table 3 Cost and income in generated material utilization stage of Present and Plan for total biomass

\begin{tabular}{|c|c|c|c|c|c|c|c|}
\hline & \multirow{2}{*}{ 段階 } & \multicolumn{3}{|c|}{ 「害拮」におけるコストと収入 } & \multicolumn{3}{|c|}{ 「計画」におけるコストと収入 } \\
\hline & & 項目名 & 金額 & 計 & 項目名 & 金額 & 柿 \\
\hline \multirow{7}{*}{$\begin{array}{l}z \\
\bar{x} \\
r\end{array}$} & $\begin{array}{l}\text { 建設 } \\
\text { - 製造 }\end{array}$ & $\begin{array}{l}\text { 水稲・畑作物生産に係る } \\
\text { インフラ等の建設・整備 } \\
\text { コスト }\end{array}$ & \multirow{3}{*}{$\begin{array}{l}\text { 「実態」と「計画」 } \\
\text { で同じため算出 } \\
\text { せず }\end{array}$} & \multirow{7}{*}{348,030 干円/年 } & $\begin{array}{l}\text { 水稲・畑作物生産に係る } \\
\text { インフラ等の建設・整備 } \\
\text { コスト }\end{array}$ & 「実態」と「計画」 & \multirow{7}{*}{$292,332 千 \mathrm{~F} / \mathrm{f}$} \\
\hline & 笔襄 & $\begin{array}{l}\text { 水稲・畑作物生産に係る } \\
\text { インフラ等の廃粪コスト }\end{array}$ & & & $\begin{array}{l}\text { 水稲・畑作物生座に係る } \\
\text { インフラ等の廃棄コスト }\end{array}$ & $\begin{array}{l}\text { で同じため算出 } \\
\text { せず }\end{array}$ & \\
\hline & \multirow{5}{*}{ 運営 } & $\begin{array}{l}\text { 水稲・畑作物生産に係る } \\
\text { 人件費* }\end{array}$ & & & $\begin{array}{l}\text { 水稲・畑作物生库に係る } \\
\text { 人件费* }\end{array}$ & & \\
\hline & & $\begin{array}{l}\text { 水稲生産の基肥用化学肥 } \\
\text { 料購入費(620ha) }\end{array}$ & 29,295 千円/年 & & $\begin{array}{l}\text { 水稲生産の基肥用消化液 } \\
\text { コスト }(620 \mathrm{ha})^{*}\end{array}$ & 27,900 千円/年 & \\
\hline & & \multirow{2}{*}{$\begin{array}{l}\text { 畑作物生産の基肥用化学 } \\
\text { 肥料購入費 }(1,574 \mathrm{ha})\end{array}$} & \multirow{2}{*}{318,735 千円/年 } & & $\begin{array}{l}\text { 畑作物生産の基肥用消化 } \\
\text { 液コスト }(1,574 \mathrm{ha})^{*}\end{array}$ & 94,440 千月/年 & \\
\hline & & & & & $\begin{array}{l}\text { 畑作物生産の基肥用化学 } \\
\text { 肥料購入費 }(1,574 \mathrm{ha})\end{array}$ & 169,992 千円/年 & \\
\hline & & $\begin{array}{l}\text { 水稲・畑作物生産の追肥 } \\
\text { 肥料・他の凟材購入曹 }\end{array}$ & $\begin{array}{l}\text { 『奏態」と「計面」 } \\
\text { で同じため算出 } \\
\text { せず }\end{array}$ & & $\begin{array}{l}\text { 水稲・畑作物生産の追肥 } \\
\text { 肥料・他の凟材購入費 }\end{array}$ & $\begin{array}{l}\text { 「実態」と「計画」 } \\
\text { で同じため算出 } \\
\text { せず }\end{array}$ & \\
\hline \multicolumn{2}{|c|}{ 収入 } & $\begin{array}{l}\text { 水稫・畑作物の肘売収入 } \\
\text { 増分 }\end{array}$ & 0 円/年 & 0 丹/年 & $\begin{array}{l}\text { 特別栽培米の販売金額增 } \\
\text { 収分 }\end{array}$ & 68,200 千山/年 & $68.2007 \mathrm{H} / 4$ \\
\hline
\end{tabular}

注)項目名に゙があるものは地域内，それ以外は地域外 
减(本シナリオでは基肥のみを対象)して栽培する特別栽 培米としての付加価值は, $10 \mathrm{a}$ 当たり 11,000 円を生み出 す結果となった。

以上, S(3)から S(5)までのコストと収入をライフサイク ルとして示したのが図 2 である。収入とコストの差は実 態で゙-535,400 千円/年，「計画」では-536,902 千円/年とな った。すなわち，豚ふん尿排水をメタン発酵する「計画」 は, 収入を生み出すものの,「実態」(污水処理)に比べて コストが大きく，ライフサイクルでの収支は減少した。

IV 担い手別の経済性と地産地消効果

\section{1 担い手別の収入とコスト}

「実態」では， $\mathrm{S}$ (3)(豚ふん尿污水処理)で発生するコスト は，盖豚農家が污水処理コストとして負担する。また， $\mathrm{S}$ (5)(基肥の $100 \%$ 化学肥料施用で農作物栽培)で発生す るコストは，農業生産者が生産コストとして負担する。 一方，「計画」でのS(4)(消化液の輸送および散布)の担い手 は, 2 通り考えられる。「計画1」ではS(3)と同じ養豚農家, 「計画2」ではS(5で消化液を利用する農業生産者である。 ただし，「計画 2」では，農業生産者が個々に消化液を輸 送・散布するのではなく，農業生産法人を組織して車両・ 機器を購入・管理し, 農業生産と併せて計画的に消化液 を輸送・散布すると考えた。

表 4 に「実態」，「計画 1」，「計画 2」について主体別に整 理したコストと収入を示す。いずれも養豚農家 10 戸全体, 農業生産者は対象農地面積全体の金額である。

養豚農家についてみると，「計画1」では「実態」で は得られなかった収入が得られる。しかし，消化液 の輸送・散布に係るコスト，特に手数料収入を上回 る人件費(表 2)のため，収支は「実態」よりも大きく 減少する。「計画 2」では，S(3)(メタン発酵十コジェ ネレーション)におけるコストは「実態」よりも増加 (図 2)するが，収入が得られるため，収支は「実態」 よりも改善される。

農業生産者についてみると，「計画1」では，「実態」よ りも安価で基肥を入手できるため，収支は「実態」の約 64\%に減少した。「計画 2」では，S(4)(消化液の輸送・散 布)のコスト(表 2, 図 2)を負担するため，「実態」と比較 して収支が減少したが，「実態」と「計画 2」の差額は 6,932 千円/年にとどまった。この金額は，対象農地面積 $10 \mathrm{a}$ 当 たりに換算すると 316 円の生産コスト増に相当する。た だし,「計画 1」の養豚農家でのコスト負担にくらべて，1 経営体当たりの金額は小さいと考えられる。たとえば, 本稿で収入増を考慮しなかった畑作物栽培において消化 液の利用により，上記の金額以上の付加価値を生み出す
ことができれば, 養豚農家と農業生産者の双方にとって， 「実態」よりも経済性が改善されると考えられる。

\section{2 バイオマス由来生成物の地産地消による効果}

IIIの結果をもとに，各ステージで発生するコストを， 地域内に支払われるものと地域外に支払われるものに分 けて集計した(表 5)。「実態」では，ライフサイクルでのコ ストのうち，約 93\%は地域外一支払われ，地域内の収入 となるのはわずか 7\%となった。一方計画」では, ライ フサイクルでのコストは全体で 1.4 倍以上になったが, そのうち約 44\%は地域内の収入となった。さらに，その 36\%(コスト全体の 15\%)は，S(3)で生成されたものに対す る支払(シナリオ内の他のステージでは収入となる)であ った。この結果から，シナリオの対象とした産業に限ら れるものの，地域内で発生するコスト(消費)のうち，バ イオマスの活用によって地域内の収入(生産・販売)とな る割合が向上することが示された。

\section{V おわりに}

本稿では，養豚業と水稲・畑作物栽培の盛んな香取市 を事例とした既往研究の結果を元に，豚ふん尿活水の処 理・放流十農作物生産の基肥に化学肥料を利用するシナ リオ(「赛態」)と，メタン発酵による電力・熱および消化 液の生成十農作物生産の基肥の全量または一部に消化液 を利用するシナリオ(「計画」)について，担い手別の経済 性を算出・評価した。その結果, 農業生産者にとっては,

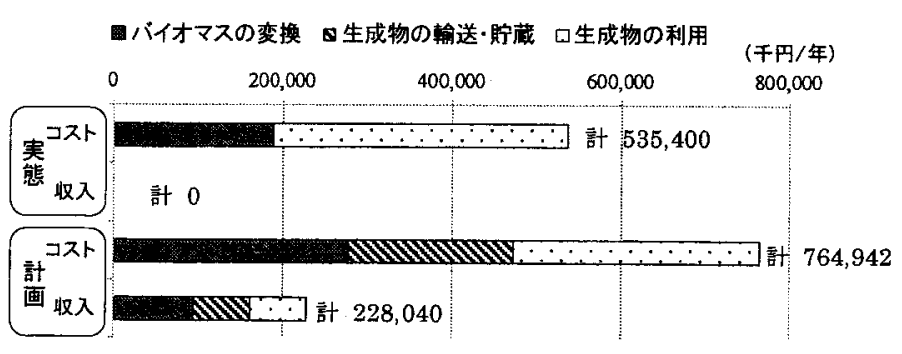

図 2 ライフサイクルでの「実態」と「計画」のコストと収入 Fig.2 Lifecycle cost and income in Present and Plan

表 4 担い手別のコストと収入

Table 4 Cost and income of each person in charge (千円/年)

\begin{tabular}{|c|c|c|c|c|}
\hline & \multicolumn{2}{|c|}{ 妻豚農家 } & \multicolumn{2}{|c|}{ 農業生産者 } \\
\hline & コスト & 収入 & コスト & 収入 \\
\hline \multirow{2}{*}{ 実態 } & 187,370 & 0 & 348,030 & 0 \\
\hline & 収支 & $-187,370$ & 収支 & $-348,030$ \\
\hline 計画 & 472,610 & 159,840 & 292,332 & 68,200 \\
\hline 1 & 収支 & $-312,770$ & 収支 & $-224,132$ \\
\hline 計画 & 275,960 & 94,020 & 488,982 & 134,020 \\
\hline 2 & 収支 & $-181,940$ & 収支 & $-354,962$ \\
\hline
\end{tabular}

表 5 コストの支払先

Table 5 Cost paid to locally and outside （千円/年）

\begin{tabular}{r|r|r|r}
\hline \hline & ライフサイクルコスト & 地域外人 & \multicolumn{1}{c}{ 地域内人 } \\
\hline 実態 & 535,400 & 498,670 & 36,730 \\
\hline 計画 & 764,942 & 425,102 & 339,840 \\
\hline
\end{tabular}


化学肥料よりも消化液を利用する方が生産コストを抑え ることができた。一方，消化液の利用のためには，輸送・ 散布に係るコストが発生(表 2)する。そのコストについ ては，発生者(養豚農家)よりも利用者(農業生産者)功負 担する方が，経済収支の改善が図りやすいことが推測さ れた。さらに、「計画」では，「実態に比べて地域内で発 生するコストが地域内に支払われる割合が高く，地域内 で生成されたバイオマス由来製品の地域内消費によって， 地域外に出ていくお金が少なくなり地域内に落ちるお金 が多くなる，といった経済的な効果が把握できた。本稿 では，評価对象について設定した詳細な条件に基づき， コストと収入を積み上げる方法を用いた。今後は，他の バイオマスの種類や活用方法についても実証的な評価を 行いたい。また，把握された効果が，より広い意味での 地域経済にどのような波及効果をもたらすかを明らかに することも今後の課題である。

※本研究は農林水産省のプロジェクト研究「地域活性化 のためのバイオマス利用具術の開発(モデル化, Cm3110)」の成果の一部である。

\section{注}

注 1) 養豚の一貫経営のモデルとして, 子取り用雌豚頭数 に加えてその $10 \%$ の頭数の種雄豚，雌豚頭数の 10 倍の頭数の子豚 (肥育豚)が飼養される条件とした。 注 2）出荷や廃畜等に伴い頭数は年間で変動するが，設 定した頭数に応じた規模の畜舎が存在するため,る ん尿排出源となる頭数は定常的な条件とみなした。 注 3 ) 電力の販売に保るコスト(変電·送電)についてはコ ストを計上していない。また余剩熱については，発 生量が少なく，また現実的に販売は難しいことから， 販売は行わないものとした。

\section{引用文献}

1 ) 寺田徹・横張真・田中伸彦(2010)：収穫・輸送コストか らみた都市近郊部平地林の木質バイオマス利用の可能 性，ランドスケープ研究，73(5)，663-666.

2 ) 前野真吾・系長浩司・藤沢直樹(2004)：木質ペレットに よるエネルギーの地産地消の可能性, 農村計画論文集, 6, 109-114.

3 )森本英嗣・橋本禅・星野敏・九鬼康彰(2010)：バイオマ スタウンを軸とした木質バイオマスの広域利用に関す る評価, 農村計画学会誌, 29 巻論文特集号, 191-196.

4) 古市徹監修・有機系廃棄物資源循環システム研究会 編著(2010) :『循環型社会の廃㲤物系バイオマスー利活 用事業成功のためのシステム化一』, 環境新聞社, 東京, pp.44-50.

5 )大久保天・秀島好昭・主籐祐功・近江谷和彦(2010)： 乳牛ふん尿主体のバイオメタン製造プラント導入によ る温室効果ガス排出削減とその経営収支に関する分析. 農業農村工学会論文集, 270, 43-55.

6 ) 菱沼竜男 - 井原智彦・志水章夫 ・楊翠芬 ・玄地裕 (2007)：LCA 手法を用いた肥育豚䔬尿処理システムの 環境影響の比較. 農業施設, 38(1)，43-56.

7 ) 清水夏樹・柚山義人・中村真人・山岡賢(2012)：バイ オマス利活用システムのライフサイクルを対象とした 経済性の評価，農工研技報，212，53-96.

8 )香取市: 香取市バイオマスタウン構想(バイオマス情 報へッドクオータ一第 40 回公表)， $<$ http://biomasstown.biomass-hq.jp/biomasstowns/a nnounce $/ 40>, 2012$ 年 7 月 25 日.

9)環境コミュニケーションズ(2002): 小規模事業場排水 処理対策全科, 小規模事業場排水対策マニュアル普及 版, 5, 121-140.

Summary: In this paper we evaluate profitability of the Present and Plan scenario on swine waste water treatment in suburban agricultural area by calculating cost and income. Present is composed discharging processed swine waste water into river and farming with chemical fertilizer application, while, in Plan, electricity and heat produced by methane fermentation and cogeneration system. The fermentation residue, which is digested slurry, also utilize as liquid fertilizer. From trial calculation, economic merit of local production for local consumption has become apparent as cost paid to local industry account for $44 \%$ in Plan against $7 \%$ in Present.

Keywords:バイオマス(biomass),コスト(cost),担い手(person in charge), 地産地消(local production for local consumption), メタ ン発酵(methane fermentation) 